\title{
DROSERA $\times$ HYBRIDA REST IN PEACE
}

John BRITTNACHER •Ashland, Oregon •USA •john@carnivorousplants.org

Keywords: history: D rosera $\times$ hybrida

In the final years of the $19^{\text {th }}$ century, the Scottish botanist] ohn Muirhead Macfarlane was unique ly situated to discover, describe, and understand a plant he named D rosera hybrida (Macfarlane 1899). He was classically trained in all the minutia rel ated to structural botany and probably spent a large part of his early life sitting at a microscope. His scientific method was to observeand describe nature, then philosophize about what he discovered.

Macfarlane's major passions were evolution and heredity. He was an adherent of Charles Darwin's theory of evolution from an early age and much of his life's work was exploring the mechanisms of evolution (see Macfarlane 1909). He understood that one of the key, but inadequately explained aspects of evolutionary theory in the late $19^{\text {th }}$ century was the mechanism for generating variation that was the grist for the struggle of the fittest. The gradual ism of Darwin was slow and did not explain how so many different species could evol ve so fast. Through his study of $N$ epenthes in general and Nepenthes hybrids in particular, Macfarlane saw that the generation of new species by hybridization could bea significant factor in evolution (Macfarlane 1889, 1893). Thesenew species were a blend of the existing species and, as he observed, could combinethe best of both parents.

In his prerediscovery of Mendel world, Macfarlane was squarely in the blending inheritance camp. Under blending inheritance, the "generative substance" in the cells of hybrids was thought to blend like paint colors producing a new species intermediate in appearance between the parent species. The generative substance was thought not to segregate or unblend in the offspring of hybrids. The hybrids were considered a new stable type and thus a new species. In 1892 while at the University of Edinburg, Macfarlane published a major paper on plant hybrids: A comparison of the minute structure of plant hybrids with that of their parents, and its bearing on biological problems (Macfarlane 1892a). In the paper he illustrated in exquisite detail how hybrids are a mix of characters present in the parents. He focused mainly on microstructural elements, measuring a range of variation in the parents and comparing them to the hybrid. To Macfarlane, the mixing of the parental traits was proof of blending inheritance and a way to produce instant species.

Macfarlane also lived in a pre-modern philosophy of science world. Before the philosopher Karl Popper in the 1930s pointed out that it was impossible to prove a theory is correct (see Popper 1959), scientists spent their time trying to amass as much data supporting their theories under the assumption that the theory with the most support was correct. After Popper, science became a more iterative process of hypothesis, prediction, and testing where scientists are involved in proving a prediction of a hypothesis is wrong rather than correct. In his attempts to prove blending inheritance was true, Macfarlane did note that occasionally he found characters that more closely match one parent or the other and wondered in his writing how that worked. But he dismissed those cases as not the norm rather than use them to question blending inheritance What baffled him most was that unlike in his study of Nepenthes where all the hybrids were fertile, D rosera $\times$ hybrida and a few other hybrids he examined were sterile and had pollen, ovules, and mature seeds not intermediate between the parents (Macfarlane 1892a). These observations did not square with his understanding of inheritanceand he presumed thegenerative substance for sexual characteristics is unable to blend 
properly. Today instead of saying, "OK, so a few observations don't fit my theory but in bulk it is true" we would focus on the observations that do not fit and say the theory is wrong. But M acfarlane was not there yet. He was on the lookout for plant hybrids, especially ones between very different parents, to accumulate yet more data to support his theories.

$M$ acfarlane was very much interested in carnivorous plants from the start of his career. In the mid 1880s, he performed a major study of the pitcher plants Nepenthes, Sarracenia, H eliamphora, Darlingtonia, and Cephalotus ( $M$ acfarlane 1889, 1893). This tour de force included descriptions of the morphology and histology of pitchers and flowers as well as arrangements for pollination and, of course, a study of Nepenthes and Sarracenia hybrids. In $1891 \mathrm{M}$ acfarlane visited the USA to give a talk on Dionaea muscipula at an A merican A ssociation for the A dvancement of Science conference. After the conference he spent three months on the east coast studying carnivorous plants including additional detailed observations on trap closure in Dionaea muscipula ( $\mathrm{M}$ acfarIane 1892b, 1892c). The abstract for his talk could have been used for a talk that was given at the ICPS 2000 conference 109 years later: timing of triggering of the trigger hairs, triggering the trap by poking the leaf anywhere on the lamina, and chemical triggering, along with a discussion of parallels between what happens in Dionaea leaves and animal nerves. While on that trip he was offered a job at the U niversity of Pennsylvania and moved there in 1893 becoming a professor of botany (Steckbeck 1943).

It comes as no surprise that when M acfarlane arrived at Penn he visited local carnivorous plant sites and it is even less of a surprise what he did when he found a hybrid between two very different sundew species. This would provide more data for his theory of inheritance! In his 1899 paper he described the trip where he discovered Drosera $\times$ hybrida:

ACCOM PA NIED by a few of my students, an excursion was made, during the third week of J une, to the rich botanizing grounds near A tco, N. J. A mongst the pine-barren swamps of that locality was an area several acres in extent, that was partially flooded, but clothed with a profuse surface vegetation of swamp or bog plants. These consisted almost entirely of the four species, Eriocaulon septangulare [E riocaulon aquaticum, Seven-angle pipewort], D rosera intermedia, D. filiformis, and a yellow-flowered U tricularia.

The later blooms of $D$. filiformis were still abundant, but the involute flower stalks of $D$. intermedia were just unrolling, and as was proved later, these did not bloom fully till the second week of J uly. Casting one's eye across the swampy mass of vegetation, the clusters of pale pink el ongated leaves of $D$. filiformis contrasted strongly with the short, dense clusters of crimson-pink leaves belonging to $D$. intermedia.

A fter a considerable stretch of the marsh had been examined, my attention was arrested by a rather distant group of plants, somewhat intermediate in height and color between the two common species around. A nearer examination of the el even plants composing the group, suggested the possibility of their being natural hybrids between the above-named species. They were carefully removed, without injury, to one of the greenhouses in the U niversity Botanic Garden, where they have since been grown and watched. A continued and careful exploration of the swamp failed to reveal the presence of additional plants or plant clusters like those already found.

Detailed comparison of the leaves, flower stalks, inflorescence, flowers and period of blooming, still further confirmed the suspicion entertained on finding them. Histological investigation of the three, as well as of $D$. rotundifolia, which was only sparingly present in the marsh, shows that the last-named species does not contribute to the formation of the plants in 
question. It equally demonstrates a minute blending, in all parts of the hybrids, of the histological peculiarities of $D$. filiformis and $D$. intermedia.

When the eleven specimens were collected, care was taken to remove sods of both parent species, and all three were grown in neighboring flats in the greenhouse.

In other words, J ohn M uirhead M acfarlane, an expert on plant hybrids with a keen interest in carnivorous plants, went to one of his favorite botanizing locations and found el even hybrid sundew plants. He then shovel collected ALL of them plus "sods" of the parental species so he could add to his proof of blending inheritance. So it goes for D rosera $\times$ hybrida at the type location.

M acfarlane's study of D rosera $\times$ hybrida is a classic example of late $19^{\text {th }}$ century botany. He measured what today we would consider all the important taxonomic details of the plants but then went into great detail about cell size, stomata size and location, chloroplast sizes and distribution among cell types, the trachea and cell structure in tentacular hairs, and then apologized for not going into the minute details of the flower ovaries and seeds. On top of this it was almost unheard of for scientific papers of this era to have tables of data. So M acfarlane was not forced to put his data in a form that required some consistency and is easy to visualize. A nd forget about statistics, it did not exist yet. Table 1 summarizes his key data as described in the text of his paper. Figure 1 shows flowers of the parents and three different hybrid clones; Figure 2 is a reproduction of the plate accompanying the text.

Table 1. Taxonomically relevant measurements from Macfarlane (1899). Measurements in English units were converted to metric.

\begin{tabular}{|c|c|c|c|}
\hline Character & D. filiformis & D. $\times$ hybrida & D. intermedia \\
\hline L eaf length & $\begin{array}{l}20 \mathrm{~cm} \text { average, } \\
\text { to } 25-28 \mathrm{~cm} \text { summer }\end{array}$ & $\begin{array}{l}\text { 4.4-5.1 cm spring, } \\
9 \mathrm{~cm} \text { average summer }\end{array}$ & $3.8 \mathrm{~cm}$ average \\
\hline L eaf petiole length & $1.0-1.6 \mathrm{~cm}$ & $\begin{array}{l}\text { 1.3-1.6 cm spring, } \\
2.2-2.5 \mathrm{~cm} \text { summer }\end{array}$ & $\begin{array}{l}\text { not mentioned in text, } \\
2.6 \mathrm{~cm} \text { from Plate } X I I\end{array}$ \\
\hline $\begin{array}{l}\text { Tentacular hair } \\
\text { color }\end{array}$ & head crimson & $\begin{array}{l}\text { head + top } 1 / 3 \text { to } 1 / 2 \\
\text { stalk crimson }\end{array}$ & $\begin{array}{l}\text { head + top } 2 / 3 \\
\text { stalk crimson }\end{array}$ \\
\hline Tentacle head size & $220 \mu \times 165 \mu$ & $210 \mu \times 125 \mu$ & $230 \mu \times 105 \mu$ \\
\hline Scape length & $25 \mathrm{~cm}$ average & $17 \mathrm{~cm}$ average & $14 \mathrm{~cm}$ average \\
\hline Number flowers & 14 average & 10 average & 8 average \\
\hline Bloom size & $22 \mathrm{~mm}$ & $9.5 \mathrm{~mm}$ & $6.4 \mathrm{~mm}$ \\
\hline Bloom period & 7 - 28 J une & until 3 A ugust & 3 July - 15 A ugust \\
\hline Bloom color & purple-pink & white/faint pink flush & white \\
\hline $\begin{array}{l}\text { Sepal glandular } \\
\text { hairs }\end{array}$ & $180-380 \mu$ long & $\begin{array}{l}1 / 4 \text { to } 1 / 3 \\
\text { D. filiformis }\end{array}$ & not present \\
\hline Sepal sessile glands & 2 and 4 celled & $\begin{array}{l}2 \text { and } 4 \text { celled, both in } \\
\text { reduced number }\end{array}$ & 2 celled \\
\hline Pollen & $\begin{array}{l}\text { richly granular, } \\
\text { up to } 56 \mu \text { across }\end{array}$ & $\begin{array}{l}\text { empty, } \\
48-50 \mu \text { across }\end{array}$ & $\begin{array}{l}\text { granular and plump, } \\
44 \mu \text { across }\end{array}$ \\
\hline Ovules & normal & $\begin{array}{l}\text { small, empty or } \\
\text { nearly empty }\end{array}$ & normal \\
\hline
\end{tabular}




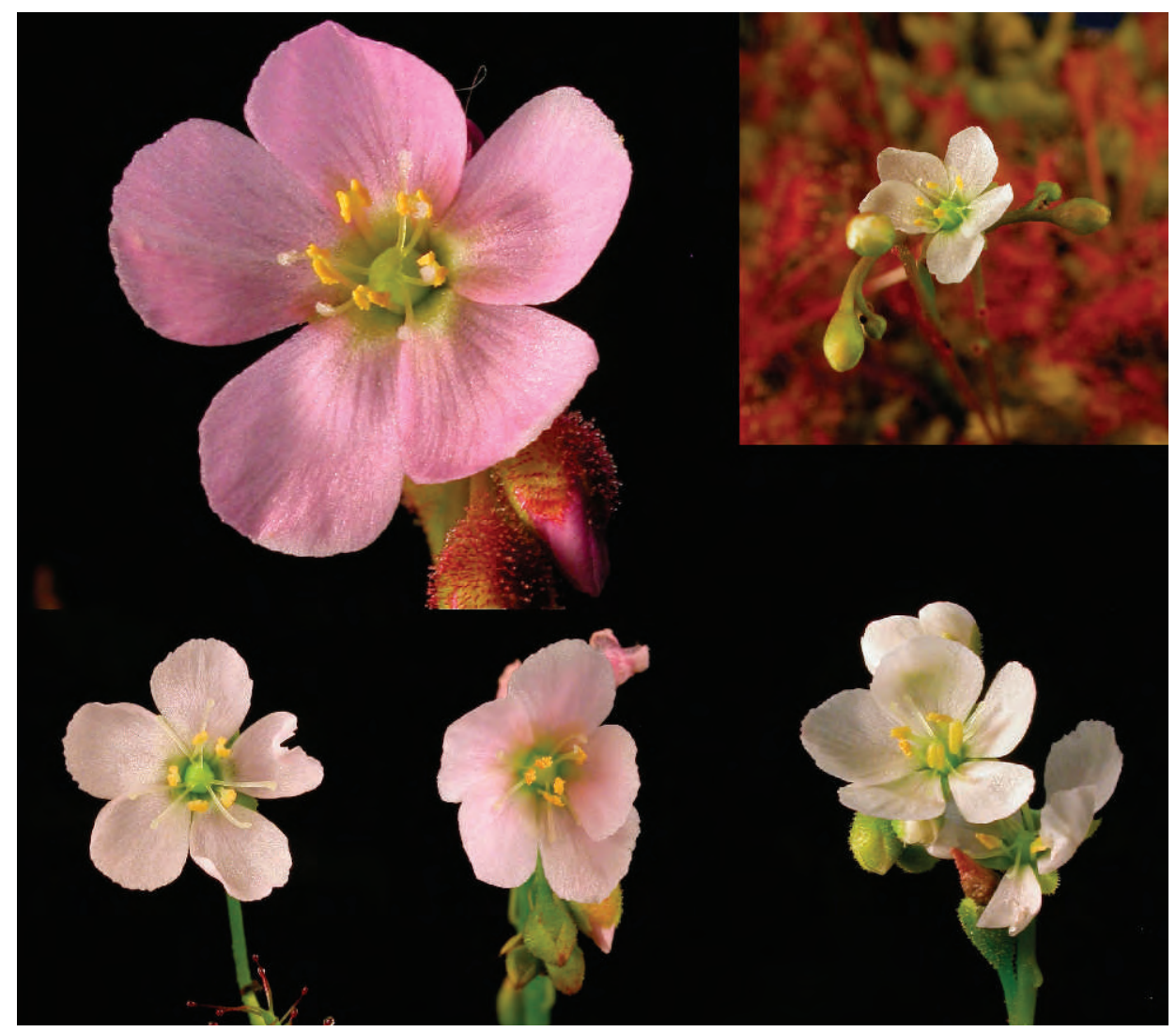

Figure 1: Flowers of Drosera filiformis and $D$. intermedia left to right on the top row. Three clones of $D . \times$ hybrida on the bottom row. The images are approximately proportional to the actual sizes. Note how the stigmas of the species are close to the stamens while in the hybrid the styles are relatively longer putting the stigmas beyond stamens. This could affect the efficiency of self-pollination.

M acfarlane summarized his data saying:

A glance at the comparative results, however, equally demonstrates that in this, as in some other hybrids studied, certain parts or organs tend more toward one parent than another. The balance of development throughout in the present case is evidently toward D. intermedia. Thus, in the relative size of the tentacular hair heads, in the amount of thickening of the indurated cortex cells, in the greatly reduced size of the glandular hairs of the sepals as inherited from D. filiformis, and in the color and size of the flowers, there is a decided preponderance in morphological detail of $D$. intermedia over the other parent, or the former exercises a certain swamping-effect on the growth vigor handed down from the latter parent. This is all the more remarkable when one considers that the apparently prepotent parent is the smaller and more delicate species. 
M acfarlane then went on to frame the result of $D . \times$ hybrida being more like $D$. intermedia than D. filiformis shoehorned into blending inheritance terms. And notice how his normally beautiful classic English prose degenerates as he starts making things up to support his theory.

The phenomenon which the writer termed bisexual hybridity [in M acfarlane 1892a] receives several striking exemplifications. Where two more or less diverse growths occurred, one on either parent, these have been shown to be reproduced not in blended fashion, but as distinct structures reduced either in size or number or both. The elongated glandular hairs on the sepals of $D$. filiformis, and the sessile two-celled glands of $D$. intermedia alike appear in the hybrid. Such a morphological pattern is frequent in hybrids whose parents are somewhat removed in systematic affinity, and suggests interesting cytological speculation. For, if every cell in the hybrid be, as its structure proclaims it to be, a combined effect of two parental conditions each reduced by half, some appropriate explanation must be given to the special case before us. [... ] It will be more consonant with the principles of heredity, if we suppose that at a certain cell centre in the epidermis, a special growth-potentiality is inherited from one parent, that stimulates to the formation of a hair characteristic of it, and that while the hereditary influence of the other parent, that is devoid of such hairs, is sufficient to reduce or check back growth of the hair to at least half the size of the parental one, it fails to prevent the devel opment of a structure peculiar to one parent al one. N either is there any need to suppose that there is a separation or sorting out of chromatic elements in the process.

The last sentence is a stab at the nascent field of genetics. M acfarlane used his data to narrate his version of heredity and developmental biology, waving his arms where he got an unexpected result, producing a modified version of blending inheritance for traits that do not blend equally. He was not prepared to believe that blending inheritance is not true or that new hybrids are not instant species. For this result $\mathrm{M}$ acfarlane sacrificed his new D rosera hybrida on the altar of science! Had M acfarlane instead focused on the traits that did not fit blending inheritance he might have made key discoveries that would have contributed to the modern synthesis of genetics and evolution. To do this he would have had to do actual experiments testing hypotheses. M acfarlane did not do experiments.

What did M acfarlane get right? M acfarlane could not have been more correct about the importance of hybridization in plant evolution and speciation. The importance of hybridization has been known at some level from the time of Carl Linnaeus but the full understanding has required genetic studies, many of which are summarized by Grant (1981). Hybridization is not only a major factor in the production of new plant species but also facilitates gene transfer between related species (Cronn \& Wendel 2004). However hybridization does not produce instant species. It may be a first step in speciation but a species is more than just one or a handful of unique individuals. M acfarlane was also right that interspecific hybrids in general are a blend of the parents. B ut virtually sterile interspecific hybrids are not the appropriate plants to study if you want to know how heredity works. To understand heredity requires using hybrids that are fully fertile and not only making first generation hybrids but also selfing the hybrids and backcrossing the hybrids to the parents. This way you can see the segregation of the genes responsible for discrete character differences. Had Macfarlane wanted to and been able to do crosses with $D . \times$ hybrida he probably could have seen the segregation of flower color in the next generation and convinced himself that blending inheritance was wrong.

What would someone in M acfarlane's position 110 years later do if they stumbled across a previously unknown plant hybrid in nature? Remember $\mathrm{M}$ acfarlane was a professor at a preeminent university. His job promotions and stature in the scientific community would depend on publishing 


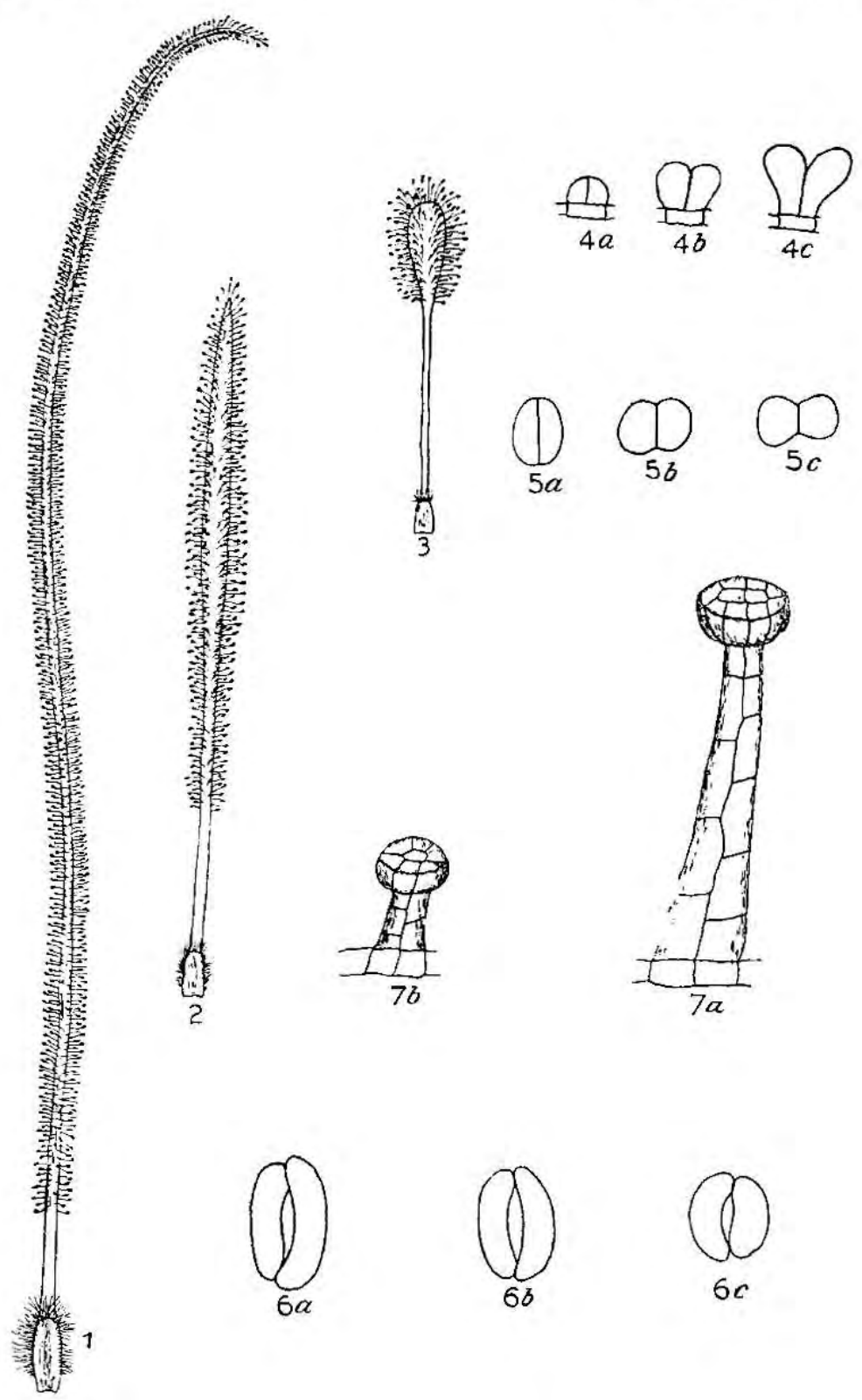

Macfarlane on Hrbrid Droseras.

Figure 2: Plate from Macfarlane (1899). 1. Leaf of Drosera filiformis. 2. Leaf of Drosera $\times$ hybrida. 3. Leaf of Drosera intermedia. 4a. Gland cells of Drosera filiformis; 4b of $D$. $x$ hybrida; $4 c$ of $D$. intermedia, all in vertical view. $5 a, 5 b, 5 c$. Surface views of last. $6 a$. Stoma of $D$. filiformis; 6 b of $D$. $\times$ hybrida; 6 c of $D$. intermedia. 7a. Capitate glandular hair from sepal of $D$. filiformis; $7 \mathrm{~b}$ of $D$. $\times$ hybrida. 
significant contributions to the field of botany. According to Steckbeck (1943) Macfarlane enjoyed teaching and interacting with students and in fact was out in the field with his students when he found his hybrid so I expect a modern Macfarlane would think "this would be a great project for my undergraduate field botany class". It would not be something on which he would spend much of his own personal research time. Hybrids are expected whenever two closely related species grow near each other, bl oom at the same time, and share pollinators. But he would hedge his bets because the parental species in this case do not normally grow with each other or bloom at the same time so he might find something worth a research publication. He might even bother to publish a name for the hybrid. Unfortunately the modern Macfarlane cannot go back to the Atco botanizing site and do a follow up to se if any more hybridization occurred. Rich Sivertsen (pers. comm) spent years looking for $D . \times$ hybrida in the Atco area and concluded after tal king to residents that theAtco bog was where a drag strip and motocross racetrack are located today.

This would be the end of the story of D rosera $\times$ hybrida if Rich Sivertsen and Dave Kutt (Sivertsen 2008) had not accidental ly discovered it in 1974 at Lake A bsegami, New J ersey, 38 $\mathrm{km}$ southeast of Atco. LakeAbsegami is an artificial lake in the Bass River State Forest, Burlington County, New Jersey. The lake has a sandy beach with a boat launch area. The higher than historical water level brought together $D$. inter media, a species usual ly found in or near shall ow water, and $D$. filiformis, which is usually found in sandy areas with the water level below the soil surface. Peter D'Amato (2011) related this story about D. intermedia from a visit to the lake as a teenager:

Onceas a kid I saw a woman moveaway from the people on themain part of the beach and she laid her towel on the sand closest to where the cove was, I think she wanted to be al one. To my teenage horror, she threw her towel right over some sundews. I went over to her and said something like "Excuse me, you're crushing rare plants lying there!" She sat up on her el bows and a sundew was uprooted sticking to her arm! I told her "that's a carnivorous plant eating your arm!" She rapidly moved to the main beach area not because she cared about sundews but because I think shethought I was insane.

As Macfarlane noted, $D$. intermedia and $D$. filiformis do not usually bloom at the same time. For some reason the two species did bl oom together at LakeA bsegami, probably from D. filiformis having delayed flowering after being stepped on, and produced a new population of $D . \times$ hybrida. Initially Sivertsen noticed stunted "D. filiformis" near the boat launch in an area of heavy traffic and thought those plants would bekilled anyway so why not collect some of them during the spring while dormant for himself and Kutt who was visiting from Ohio. By summer Sivertsen and Kutt real ized something was wrong with their new " $D$. filiformis". The leaves were short and wide with petioles too long plus the flowers opened white and closed with a light purple flush. Sivertsen sent plants to Don Schnell and J oe Mazrimas for identification. Schnell responded that the plant was the long lost D . $\times$ hybrida. Sivertsen distributed the plants widely including Europeand J apan.

Schnell visited the Lake Absegami plants with Sivertsen later in 1974 (Schnell et al. 1974). It was noted that the $D . \times$ hybrida plants occurred singly and in clumps among the parent species and that there semed to be variation among the hybrids. Some plants were more D. filiformis-like but most were definite intermediates between the parents. I wonder what Macfarlane would have thought of the D. filiformis-like plants! The last known record of D. $\times$ hybrida at this location was May 2008 (see Front Cover). Sivertsen (pers. comm) visited Lake Absegami in August 2011 and fail ed to find any $D . \times$ hybrida. No $D$. fil iformis were present either and had not been for a few years 


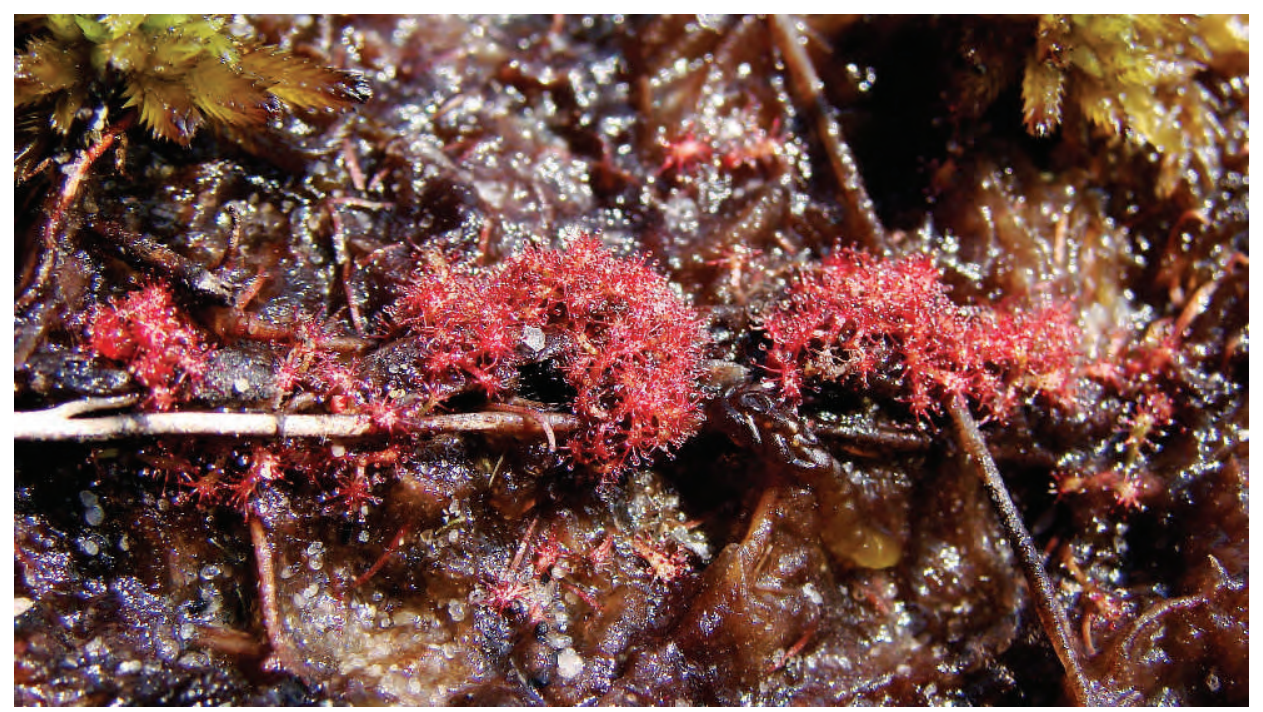

Figure 3: Drosera filiformis seedlings growing from seedpods on an intact flower stalk. The Martha Furnace Drosera $\times$ hybrida were found under a similar situation although the plants were almost blooming size. Photo by Jason Ksepka.

so a regeneration of the hybrid could not happen there again. So it goes for the second coming of $D$. $\times$ hybrida in a natural population.

In 1978, Jim B ockowski, while giving Philip Sheridan and M ike Hunt a tour of the pine barrens (Sheridan 1978) discovered D. $\times$ hybrida near the ruins of M artha Furnace, B urlington County, N ew J ersey. Martha Furnace was an early $19^{\text {th }}$ century bog iron smelter along a branch of the Oswego River in the pine barrens $10 \mathrm{~km}$ northwest of Lake A bsegami. The ore deposits were scraped off the banks of the rivers, melted into pigs at the furnace, and boated down the rivers to the coast. The location where the plants were found was where a bank had eroded into an inlet to the river branch forming a sandy area with $D$. intermedia growing in a solid mat along and in the water and thousands of $D$. filiformis growing a meter or two from the water. Several clumps of $D . \times$ hybrida plants were growing out of the seedpods of one flower stalk in the mud near the D. intermedia (B ockowski pers. comm., see Fig. 3). B ockowski collected one of the clumps and over the next few years distributed plants and leaf cuttings widely. Bockowski and others have returned to the location several times since 1978 but have not been able to find any $D . \times$ hybrida. So it goes for the third coming of $D . \times$ hybrida.

Was the Lake Absegami D. $\times$ hybrida actually a "natural" population and for that matter was M acfarlane's roadside bog "natural" or Bockowki's sand slump? Lake A bsegami is a very disturbed area ecologically. The plants are in the middle of a recreational area where families go to play. Sivertsen regularly took his family there on vacation. D'A mato was there with his family. It is highly possible the A tco bog was also not fully natural. In the mid to late $19^{\text {th }}$ century, A tco, N ew Jersey, was in a major glass producing area with a 3000-acre production area nearby (The A tco Town Crier 2008). The M artha Furnace location was in an area with major disturbance a century prior to the plants being there. Bockowski did not think it looked "disturbed" at the time although it was not exactly a stable or typical site. What is apparent is that it takes special circumstances to produce an environment where the hybridization can occur and those locations may be transient. 
Whether it takes human disturbance or not to produce D rosera $\times$ hybrida, it has not been found anywhere else. In well over 40 years exploring the N ew Jersey pine barrens, Sivertsen and others have observed many sites where both $D$. intermedia and $D$. filiformis occur in very close proximity without finding any hybrids between them. Schnell (2002) reports that he also failed to find D. $\times$ hybrida where $D$. intermedia and D. filiformis grow together in North Carolina and Florida. A gain, the most likely reason for this is $D$. filiformis blooms in the early summer while $D$. intermedia blooms in the late summer. To get the hybrid, something has to happen to make $D$. intermedia bloom early or D. filiformis bloom late.

As far as is known, all D. $\times$ hybrida in cultivation are either from an area the size of a dining room table at $L$ ake A bsegami, one clump of plants from one seedpod at $M$ artha Furnace, or are artificial hybrids. It is not known how many clones of $D . \times$ hybrida exist. It is possible there are clones produced from seeds. A s M acfarlane found, the plants produce pollen and seeds but all the ones he examined were hollow. This means that at an extremely low rate $D . \times$ hybrida should produce viable seed because the plants have the functional machinery to produce pollen and seeds. During meiosis the unpaired chromosomes segregate more or less at random or do not segregate at all. This is what causes the apparent sterility. For D. $\times$ hybrida the pollen and ovules could contain no genetic material, or all 20 chromosomes, or any number of chromosomes in between. To get a viable seed would require an ovule to be pollinated with pollen containing a complementary set of chromosomes. A ny of the rare viable seeds with a full complement of chromosomes, and thus the new plants, could be an exact duplicate of the original clone (the exact same 20 chromosomes), aneuploids (uneven assortment of chromosomes), triploids (double set from one parent and single set from the other with 30 chromosomes), or tetraploids (double duplicate of the original with 40 chromosomes). Anyone who has enough of the plants should be able to produce progeny of each of these types via seed. However I think most if not all the clones represented in captivity result from different hybridization events. It is quite possible each of the plants collected by Sivertsen represented different clones. I have identified clones with different leaf lengths and flower colors. Of these the only one I can confidently trace back to Lake A bsegami has the longest leaves and pale pink flowers. The most common clone on the west coast probably descends from the plants Sivertsen sent to J oe M azrimas and it has relatively short leaves and al most white flowers. I cannot confirm this because $M$ azrimas (pers. comm.) was unable to maintain the plants long term at his house in the mild climate of the San Francisco bay area. We could maintain what appeared to be a different clone in Davis $90 \mathrm{~km}$ to the northeast but the plants were dormant 8 months of the year and thus quite boring. They were discarded. B ecause we were dealing with virtually sterile clones there was no easy way to select for a clone that grew well in captivity.

Even though no natural $D . \times$ hybrida are now known in the wild, that is no reason to plant out the plants on private property you do not ow n or on public property or even at the locations where they were discovered. There is nothing special from a modern scientific or conservation point of view about D . $\times$ hybrida and especially the original wild clones. M acfarlane did an excellent job characterizing the nature of the hybrid. What he did not understand is how common plant hybrids are and the vast majority of them suffer the same fate as $D . \times$ hybrida. From a conservation standpoint, $D$. $\times$ hybrida is not a plant typical of the $\mathrm{N}$ ew J ersey pine barrens. The plants at $L$ ake $A$ bsegami cannot predate the artificial lake, it is unlikely the eleven plants at A tco predate the sand mining and logging of the $19^{\text {th }}$ century, and the few plants at $M$ artha Furnace could not have been more than one or two years old.

For horticulturalists D. $\times$ hybrida is a fascinating plant. There are nice diploid clones of $D . \times$ hybrida available from artificial crosses and some day there will be a fertile tetraploid available. The 
L ake A bsegami clones are not the easiest to grow. They are temperate plants with a very short growing season. Forget about growing them long term in a terrarium or outside in a mild climate. What would be most interesting is to make new clones of $D . \times$ hybrida with parents from different locations, say the Florida D. filiformis and the Cuban D. intermedia. These plants would make better hobby plants. It may also be possible to make hybrids between $D$. tracyi and $D$. intermedia. That could be a fun plant! All you need is plants of both species blooming at the same time to make your own hybrid.

A cknowledgements. I thank Leslie Gottlieb, Ron Lane, Rich Sivertsen, Jim Bockowski, J oe M azrimas, Jason K sepka, Peter D'A mato, and Andreas Fleischmann for help and comments on the manuscript.

\section{References}

The A tco Town Crier. 2008. The Story Of A tco's B eginnings. http://theatcotowncrier.com/2008/11/ atcos-beginnings/. A ccessed 23 J uly 2011.

Cronn, R., and Wendel, J.F. 2004. Cryptic trysts, genomic mergers, and plant speciation. N ew Phytologist. 161(1): 133-142.

D'A mato, P. 2011. E-mail message posted to Carnivorous Plant Discussion Group, 28 July 2011. http://omnisterra.com/mailman/listinfo/cp_omnisterra.com.

Grant, V. 1981. Plant Speciation. Columbia University Press, New York, USA.

M acfarlane, J.M. 1889. O bservations on pitchered insectivorous plants. (Part I.). A nnals of Botany 3(10): 253-266.

M acfarlane, J.M. 1892a. A comparison of the minute structure of plant hybrids with that of their parents, and its bearing on biological problems. Trans. Royal Soc. Edinburgh 37(14): 283-286.

M acfarlane, J.M. 1892b. A nother chapter in the history of Venus fly-trap. Proceedings, The A merican Association A dvancement of Science for the fortieth meeting, Washington, DC, August 1891, p 318.

M acfarlane, J.M . 1892c. Contributions to the history of D ionaea muscipula Ellis. Contrib. B ot. Lab. Penna. 1: 7-44.

M acfarlane, J.M . 1893. Observations on pitchered insectivorous plants. (Part II.). A nnals of B otany 7(4): 403-455.

M acfarlane, J.M . 1899. O bservations on some hybrids between D rosera filiformis and D. intermedia. Trans. Proc. B ot. Soc. Penna. 1: 87-99. (also Contrib. B ot. L ab. Penna. 2: 87-99. 1898)

M acfarlane, J.M . 1909. Charles Darwin: three appreciations. Cornell U niversity Library's print collections.

Popper, K. 1959. The logic of scientific discovery (translation of L ogik der Forschung). Hutchinson, London.

Schnell, D., Sivertsen, R., and K utt, D. 1974. News and V iews. Carniv. PI. N ewslett. 3(3): 34.

Schnell, D.E. 2002. Carnivorous plants of the U nited States and Canada, 2nd edition. Timber Press, Portland, Oregon, USA.

Sheridan, P. 1978. N ew Jersey Pine Barrens. Carniv. PI. N ewslett. 7(4): 107-109.

Sivertsen, R. 2008. ICPS Forum: http://icps. proboards.com/index.cgi ?board=drosera\& action=display $\&$ thread=1921. A ccessed 11 J uly 2011.

Steckbeck, W. 1943. O bituary: J ohn M uirhead M acfarlane. Science 98(2553): 487-488. 


\section{CARNIVOROUS PLANT NEWSLETTER}

Journal of the International Carnivorous Plant Society

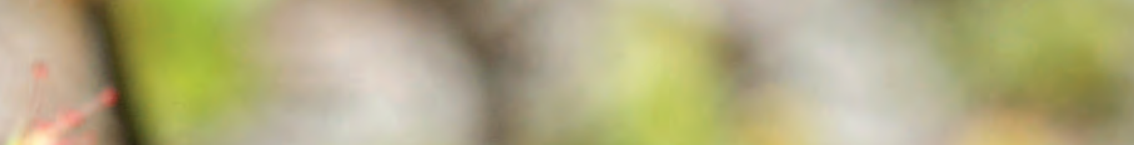

Nivi: $\%$ is
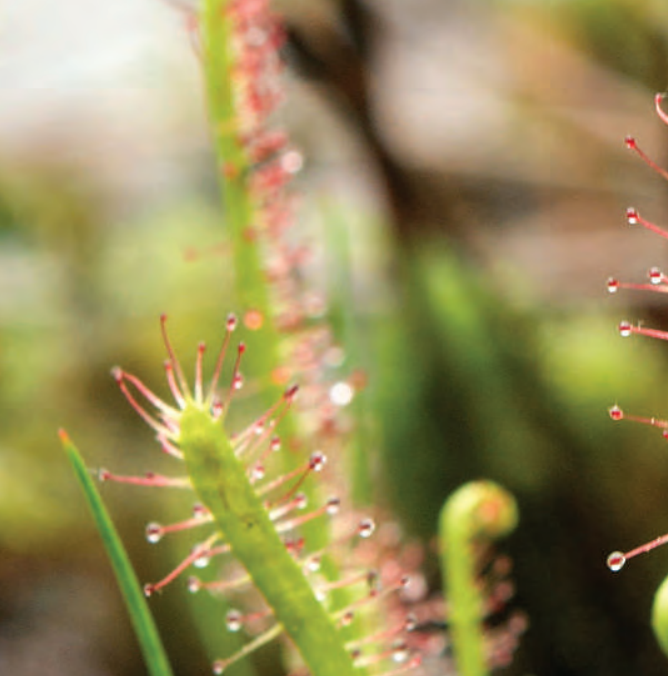
$x=2$ 14 \& if $y$

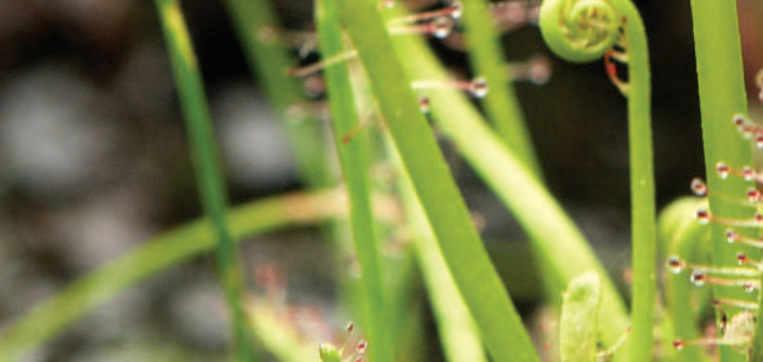
r.tien 3 $-\infty, 0^{4}$ and

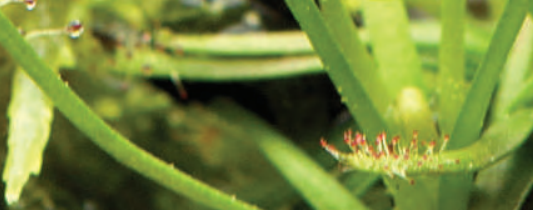




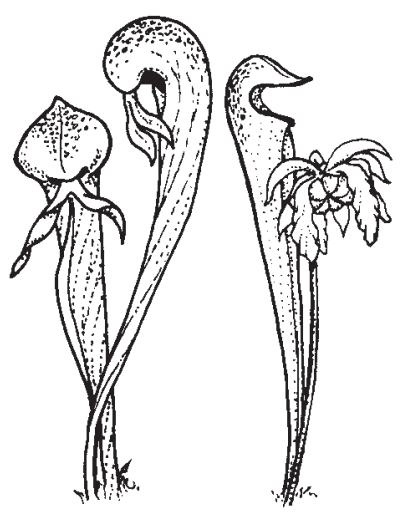

\section{CARNIVOROUS \\ PLANT \\ NEWSLETTER}

Journal of the International

Carnivorous Plant Society

www.carnivorousplants.org

Volume 40, Number 4 December 2011

\section{Front Cover: Possibly the last photo of Drosera x hybrida at Lake Absegami, New Jersey. Photo taken 11 May 2008 by Jason Ksepka. Article on page 112. \\ Back Cover: Sarracenia 'Deep Throat'. Photo by Damon Collingsworth. Article on page 139.}

Carnivorous Plant N ewsletter is dedicated to spreading knowledge and news related to carnivorous plants. Reader contributions are essential for this mission to be successful. Do not hesitate to contact the editors with information about your plants, conservation projects, field trips, or noteworthy events. A dvertisers should contact the editors. Views expressed in this publication are those of the authors, not the editorial staff.

All correspondence regarding dues, address changes and missing issues should be sent to the Membership Coordinator at the ICPS. D o not send such correspondence to the editors. Checks for subscriptions should be made to the ICPS in US funds. Dues for 2012 are $\$ 35$ for the first year of membership; renewals are $\$ 30$ per year.

ICPS, InC.

2530 Patra Drive

Richmond, CA 94803, USA

icps@carnivorousplants.org

President Michael Baldwin, michael@ carnivorousplants.org

Vice President M Marcel van den B roek, marcel@ carnivorousplants.org

Secretary_ Cindy Slezak, cindy@ carnivorousplants.org

Treasurer Richard M yers, richard@ carnivorousplants.org

B oard M ember B B Ziemer, bob@carnivorousplants.org

Board M ember Jan Schlauer, jan@ carnivorousplants.org

B oard M ember B Brian Barnes, Conservation Director, brian@ carnivorousplants.org

Seed B ank M anager J ohn B rittnacher, john@ carnivorousplants.org (see seed bank ad in this issue)

Editors:

M anaging Editor

Science Editor

Bob Ziemer, bob@carnivorousplants.org

$\begin{array}{ll}\text { Editor } & \text { Fernando Rivadavia, fernando@ carnivorousp }\end{array}$

Date of effective publication of the September 2011 issue of Carnivorous Plant N ewsletter: 1 September 2011.

The ICPS is the International Cultivar Registration A uthority (ICRA) for the names of cultivated carnivorous plants according to the International Code of N omenclature for Cultivated Plants. Send relevant correspondence to the ICPS, Inc.

Carnivorous Plant N ewsletter is published quarterly in M arch, J une, September, and December by the ICPS, Inc., 2530 Patra Drive, Richmond, CA 94803, USA. Periodicals postage pending at Richmond, CA and additional mailing offices. Postmaster: Send address changes to ICPS, Inc., PM B 322, 1564-A Fitzgerald Drive, Pinole, CA 94564-2229, USA. Printed by Allen Press, Inc., 810 E. 10th Street, L awrence, K S 66044. L ogo and masthead art: Paul M ilauskas. (c) 2011 Carnivorous Plant N ewsletter. All rights reserved. ISSN \#0190-9215 